DOI 10.22460/infinity.v7i1.p1-6

\title{
THE STRATEGY OF FORMULATE-SHARE-LISTEN-CREATE TO IMPROVE VOCATIONAL HIGH SCHOOL STUDENTS' MATHEMATICAL PROBLEM POSING ABILITY AND MATHEMATICAL DISPOSITION ON PROBABILITY CONCEPT
}

\author{
Tina Rosyana ${ }^{1}$, M. Afrilianto ${ }^{2}$, Eka Senjayawati ${ }^{3}$ \\ ${ }^{1,2,3}$ IKIP Siliwangi, Jl. Terusan Jenderal Sudirman, Cimahi, West Java, Indonesia \\ ${ }^{1}$ tinarosyana@ikipsiliwangi.ac.id, ${ }^{2}$ muhammadafrilianto1@ikipsiliwangi.ac.id, \\ 3 ekasenjayawati@ikipsiliwangi.ac.id
}

Received: March 27, 2017 ; Accepted: January 29, 2018

\begin{abstract}
This study aims to examine the improvement of students' mathematical problem posing ability and mathematical disposition through the strategy of Formulate-Share-Listen-Create (FSLC) on probability concept. The method used in this research is the experimental method, with the design of pretest-posttest control group. The population is all students of the vocational high school in Cimahi, while the sample was selected two classes from one of the vocational high school selected at random. The instrument of a test in the form of description is used to measure students' mathematical problem posing ability, while the non-test instrument is questionnaire of mathematical disposition scale. The results showed (1) The mathematical problems posing of the students who obtained FSLC learning strategy is better than that of those who obtained conventional one; (2) The improvement of mathematical problems posing of the students who obtained FSLC learning strategy is better than that of those who obtained conventional one; (3) The mathematical disposition of students who obtained FSLC learning strategy is better than that of those who obtained conventional learning.
\end{abstract}

Keywords: Disposition, Formulate-Share-Listen-Create, Problem Posing.

\begin{abstract}
Abstrak
Penelitian ini bertujuan untuk menelaah peningkatan kemampuan problem posing dan disposisi matematis siswa dengan Strategi Formulate-Share-Listen-Create (FSLC) pada konsep peluang. Metode yang digunakan dalam penelitian ini adalah eksperimen, dengan desain kelompok kontrol pretes-postes. Populasinya adalah seluruh siswa SMK di Kota Cimahi, sedangkan sampelnya dipilih dua kelas dari salah satu SMK yang dipilih secara acak. Instrumen penelitian ini yaitu tes bentuk uraian dalam kemampuan problem posing matematis, skala disposisi matematis, dan pedoman observasi. Hasil penelitian menunjukkan bahwa (1) Kemampuan problem posing matematis siswa yang memperoleh pembelajaran dengan strategi FSLC lebih baik daripada yang memperoleh pembelajaran biasa; (2) Peningkatan kemampuan problem posing matematis siswa yang memperoleh pembelajaran dengan strategi FSLC lebih baik daripada yang memperoleh pembelajaran biasa; (3) Disposisi matematis siswa yang memperoleh pembelajaran dengan strategi FSLC lebih baik daripada yang memperoleh pembelajaran biasa.
\end{abstract}

Kata Kunci: Disposisi, Formulate-Share-Listen-Create, Problem Posing.

How to Cite: Rosyana, T., Afrilianto, M., \& Senjayawati, E. (2018). The Strategy of Formulate-Share-Listen-Create to Improve Vocational High School Students' Mathematical Problem Posing Ability and Mathematical Disposition on Probability Concept. Infinity, 7 (1), 1-6. doi:10.22460/infinity.v7i1.p1-6 


\section{INTRODUCTION}

In mathematics learning, problem posing process is very important, especially in the middle school. NCTM (2000) recommended that mathematical problem formulate based on many situational, whether outside or inside mathematics, arranging and finding conjecture, also learning to generate and to extend problems through problem posing.

Kilpatrick, Swafford, \& Findell (2001) stated, "Problem posing is an essential content in mathematics and nature of mathematical thinking, as well as an important part of mathematical problem solving. According to da Ponte \& Henriques (2013), "Investigation of mathematics affords a great opportunity to bring up the problem posing". It is based on the view that the problem posing can trigger the on-going of mathematical activities through the process of asking questions. Kilpatrick, Swafford, \& Findell (2001) stated the quality of the questions students describes their abilities in solve the problem. In fact, according to da Ponte and Henriques (2013), "At the heart of mathematics is to pose a problem and solve it". Mayadina (2012) stated that mathematical problem posing consist of two aspect are accepting and challenging.

However, according to Sumarmo (2015), in contrast to the large attention to the discussion of mathematical problem solving, the mathematics curriculum has not paid much attention to the discussion of mathematical problem posing (MPP). Other than, the reality on the ground shows that vocational high school students are more geared to master certain applied skills, so the ability of problem posing is appropriate to be trained to assist them in solving mathematical problems. Besides demanded to have the mathematical problem posing ability, students are expected also to make improvement of their performance in learning through the positive behavior as part of the soft skills.

In connection with students' affective, Sumarmo (2013) argued, "Mathematical soft skills as components of mathematical thinking process in the affective domain are characterized by affective behavior shown by someone when executing mathematical hard skill. The affective behavior is associated with the term disposition showing a tendency to behave with a strong impetus. "Mathematical disposition is also demonstrated through strong dedication to positively thinking. Mathematical disposition is the correlation and appreciation of mathematics that is a tendency to think and act in a positive way (Bernard, 2015). Then, according to Polking (Hidayat, 2012; Sumarmo, Hidayat, Zukarnaen, Hamidah, \& Sariningsih, 2012), "mathematical disposition indicates: 1) Confidence in using mathematics; 2) Flexibility in solving problems; 3) Persistence in working on mathematical tasks; 4) Interest, curiosity, and discovery power in performing mathematical tasks; 5) Monitoring and reflecting their own performance and reasoning; 6) Assessment of the application of mathematics to other situations in mathematics and everyday experience; 7) Appreciation of the role of mathematics in culture and values, mathematics as a tool, and as a language. However, according to Sugilar (2013) state that this moment, the students' mathematical power and disposition has not been fully achieved.

One of the effort that is expected to improve the student's mathematical problem posing and mathematical disposition by applying learning strategies with grouping. Kilpatrick, Swafford, \& Findell (2001) stated that problem solving can be done easily through discussions in large groups, but the problem-solving process will be more practical when done in small groups working together. One of the learning strategies that can be applied is the Formulate-ShareListen-Create Strategy. 
For the sake of students' character development, Sumarmo (2013) stated that mathematical learning can help students to form their character or personality in various ways. Selection of strategies in mathematics learning can form students' characters. Therefore, we need a learning strategy to improve students' mathematical problem posing ability and mathematical disposition. This strategy can make them active, train them to collaborate and help each other in solving a given problem and provide opportunities find themselves and understand the material more deeply.

FSLC is a form of cooperative learning in small groups and is a modification of the ThinkPair-Share (TPS) strategy. FSLC which includes the steps as follows: a) Formulate: the activity of recording information related to the duties and making plans for settlement; $b$ ) Share: students share their opinions with their partner; c) Listen: each pair mutually hear from other couples, and note the differences and similarities of the opinions; d) Create: students discuss to reach a conclusion.

\section{METHOD}

The method used in this study is experimental method, with the design of pretest-posttest control group. In this type of design there is a grouping of randomized subjects (A), the pretest $(\mathrm{O})$, and their posttest $(\mathrm{O})$. The research design is like the followings:
A $\mathrm{O}$
$\mathrm{X}$
$\mathrm{O}$
A $\mathrm{O}$
$\mathrm{O}$

Notes:

A : The selection of a random sample of classes at population

$\mathrm{O} \quad$ : Pretest $=$ posttest (test of mathematical problem posing and mathematical disposition ability)

X : The application of FSLC learning strategy

The population is students in one of vocational high school in Kota Cimahi. The samples in this study are two classes randomly selected from class XI SMK. Students in the experimental class who obtained FSLC learning strategy, while students in control class who obtained conventional learning. The instrument used in this research are: 1) Mathematical problem posing anality test, 2) Mathematical disposition scale, and 3) Student observation guidelines.

\section{RESULTS AND DISCUSSION}

\section{Results}

The data were analyzed by descriptive and inferential statistical analysis. All data is processed by Microsoft Excel 2007 and SPSS 17. Here are described the results of research and its discussion. Before performing data analysis, first is presenting the data descriptive statistics of pretest ability of mathematical problem posing (MPP). The descriptive data of students' mathematical problem posing are presented in the following Table 1. 
Table 1. Descriptive Statistics Mathematical Problem Posing Ability (MPP)

\begin{tabular}{cccc}
\hline Test & Class & Statistic & $\begin{array}{c}\text { Statistical } \\
\text { Values }\end{array}$ \\
\hline Pretest & FSLC & $\overline{\mathrm{x}}$ & 7.13 \\
& & $\mathrm{~S}$ & 1.33 \\
& $\mathrm{CL}$ & $\overline{\mathrm{x}}$ & 7.15 \\
& & $\mathrm{~S}$ & 1.81 \\
\hline Posttest & FSLC & $\overline{\mathrm{x}}$ & 15.73 \\
& & $\mathrm{~S}$ & 2.59 \\
& $\mathrm{CL}$ & $\overline{\mathrm{x}}$ & 14.26 \\
& & $\mathrm{~S}$ & 3.69 \\
\hline N-Gain & FSLC & $\overline{\mathrm{x}}$ & 0.51 \\
& & $\mathrm{~S}$ & 0.15 \\
& \multirow{2}{*}{ CL } & $\overline{\mathrm{x}}$ & 0.42 \\
& & $\mathrm{~S}$ & 0.21 \\
\hline Disposition & FSLC & $\overline{\mathrm{x}}$ & 98.53 \\
& & $\%$ & 82.11 \\
& \multirow{2}{*}{$\mathrm{CL}$} & $\overline{\mathrm{x}}$ & 91.57 \\
& & $\%$ & 76.31 \\
\hline
\end{tabular}

The data analysis of posttest results aims to test the first hypothesis, which is to find out the mathematical problem posing ability between the FSLC learning strategy and the conventional learning. The statistic used is t-test. The result of statistical t-test are presented in the following Table 2:

Table 2. T-test Results of Posttest Data of Mathematical Problem Posing Ability

\begin{tabular}{ccc}
\hline $\begin{array}{l}\text { Asymp.Sig. } \\
\text { (2-tailed) }\end{array}$ & $\begin{array}{l}\text { Asymp.Sig. } \\
\text { (1-tailed) }\end{array}$ & Conclusion \\
\hline 0.054 & 0.027 & Reject $\mathrm{H}_{0}$ \\
\hline
\end{tabular}

According to the table above, it is obtained that the value Asymp.Sig (one-tailed) is 0.027 which is less than mathematical problem posing of students who obtained FSLC learning strategy is better than that of those who obtained conventional learning on probability concept.

$\mathrm{N}$-Gain data analysis aims to test the second hypothesis, which is to find out the improvement of mathematical problem posing ability between the FSLC learning strategy and the conventional learning on probability concept. The statistic used is t-test. The result of statistical t-test are presented in the following Table 3: 
Table 3. T-test Results of N-Gain Data towards the Ability of Mathematical Problem Posing

\begin{tabular}{ccc}
\hline $\begin{array}{c}\text { Asymp.Sig. } \\
\text { (2-tailed) }\end{array}$ & $\begin{array}{l}\text { Asymp.Sig. } \\
\text { (1-tailed) }\end{array}$ & Conclusion \\
\hline 0.053 & 0.0265 & Reject $\mathrm{H}_{0}$ \\
\hline
\end{tabular}

According to the table above, it is obtained that the value Asymp.Sig (one-tailed) is 0.0265 which is less than $\alpha=0.05$, so $\mathrm{H}_{0}$ is rejected and $\mathrm{H}_{1}$ accepted. This means that the improvement of students' mathematical problem posing ability who obtained FSLC learning strategy is better than that of those who obtained conventional learning.

The analysis of disposition aims to test the third hypothesis, which is it to examine the mathematical disposition between the FSLC learning strategy and the conventional learning. The statistic used is t-test. The result of statistical t-test are presented in the following Table 4:

Tabel 4. The Results of t-test of Mathematical Disposition Data

\begin{tabular}{ccc}
\hline $\begin{array}{c}\text { Asymp.Sig. } \\
\text { (2-tailed) }\end{array}$ & $\begin{array}{c}\text { Asymp.Sig. } \\
\text { (1-tailed) }\end{array}$ & Conclusion \\
\hline 0.048 & 0.024 & Reject $\mathrm{H}_{0}$ \\
\hline
\end{tabular}

Based on the Table above, it is obtained that the value Asymp.Sig (one-tailed) is 0.024 which is less than $\alpha=0.05$, so $\mathrm{H}_{0}$ is rejected and $\mathrm{H}_{1}$ accepted. This means that the mathematical disposition of students who obtained FSLC learning strategy is better than that of those who obtained conventional learning.

\section{Discussion}

FSLC is a strategy of learning in small groups in pairs which contains steps: formulating their own opinion, sharing opinions with other couple friends, and deducing by combining the best ideas. This research aims to examine: 1) The improvement students' mathematical problem posing ability through FSLC learning strategy compared to those who obtained conventional learning on probability concept; and 2) The students' mathematical disposition through FSLC learning strategy compared to those who obtained conventional learning on probability concept.

In general, the implementation of FSLC learning strategy has run well and been in line with expectations. Statistical tests conducted towards the posttest data showed that the students' mathematical problem posing ability who obtained FSLC learning strategy is better than that of those who obtained the conventional learning. Then, the statistical tests conducted towards $\mathrm{N}$-Gain data showed that the increased students' mathematical problem posing ability who obtained FSLC learning strategy is better than those who obtained conventional learning. Furthermore, the analysis of mathematical disposition showed that students who obtained FSLC learning strategy are better than that of those who obtained the conventional learning. The results of this research are equal with the results of the research by Anggraeni (2013) showed that implementing FSLC was able to improve students' mathematical understanding and mathematical communication abilities better than that of conventional approach. Students' mathematical understanding and communication abilities were classified as mediocore. 


\section{CONCLUSION}

The conclusions of this research are: (1) The mathematical problems posing of the students who obtained FSLC learning strategy is better than that of those who obtained conventional one; (2) The improvement of mathematical problems posing of the students who obtained FSLC learning strategy is better than that of those who obtained conventional one; (3) The mathematical disposition of students who obtained FSLC learning strategy is better than that of those who obtained conventional learning.

\section{REFERENCES}

Anggraeni, D. (2013). Meningkatkan kemampuan pemahaman dan komunikasi matematik siswa SMK melalui pendekatan Kontekstual dan strategi Formulate-Share-ListenCreate (FSLC). Infinity Journal, 2(1), 1-12.

Bernard, M. (2015). Meningkatkan kemampuan komunikasi dan penalaran serta disposisi matematik siswa SMK dengan pendekatan kontekstual melalui game adobe flash cs 4.0. Infinity Journal, 4(2), 197-222.

da Ponte, J. P., \& Henriques, A. (2013). Problem posing based on investigation activities by university students. Educational Studies in Mathematics, 83(1), 145-156.

Hidayat, W. (2012). Meningkatkan Kemampuan Berpikir Kritis dan Kreatif Matematik Siswa SMA Melalui Pembelajaran Kooperatif Think-Talk-Write (TTW). In Seminar Nasional Penelitian, Pendidikan dan Penerapan MIPA.

Kilpatrick, J., Swafford, J., \& Findell, B. (2001). Adding it up: Helping children learn mathematics. Washington, DC: National Academy Press.

Mayadina, S. (2012). Meningkatkan Kemampuan Problem Posing Matematika Mahasiswa Calon Guru SD Melalui Model Pembelajaran SCPBL. EduHumaniora, 3(1).

NCTM. (2000). Principles and standards for school mathematics. USA: The National Councils of Teachers of Mathematics.

Sugilar, H. (2013). Meningkatkan Kemampuan Berpikir Kreatif dan Disposisi Matematik Siswa Madrasah Tsanawiyah Melalui Pembelajaran Generatif. Infinity Journal, 2(2), 156-168.

Sumarmo, U. (2013). Kumpulan makalah berpikir dan disposisi matematik serta pembelajarannya. Bandung: Fakultas Pendidikan Matematika dan Ilmu Pengetahuan Alam Universitas Pendidikan Indonesia Bandung.

Sumarmo, U. (2015). Mathematical Problem Posing: Rasional, Pengertian, Pembelajaran, dan Pengukurannya. Retrieved from STKIP Siliwangi: http://utarisumarmo.dosen.stkipsiliwangi.ac.id/files/2015/09/Problem-Posing-MatematikPengertian-dan-Rasional-2015.pdf.

Sumarmo, U., Hidayat, W., Zukarnaen, R., Hamidah, M., \& Sariningsih, R. (2012). Kemampuan dan Disposisi Berpikir Logis, Kritis, dan Kreatif Matematik (Eksperimen terhadap Siswa SMA Menggunakan Pembelajaran Berbasis Masalah dan Strategi Think-Talk-Write). Jurnal Pengajaran MIPA, 17(1), 17-33. 